Ewa OSEK

(Lublin, KUL)

\title{
„POZNAJ SAMEGO SIEBIE” W INTERPRETACJI BAZYLEGO WIELKIEGO
}

\section{I. „POZNAJ SAMEGO SIEBIE” W ROZUMIENIU POTOCZNYM I W INTERPRETACJI FILOZOFICZNEJ}

1. Napis delficki. Teksty źródłowe odnoszące się do słynnego delfickiego

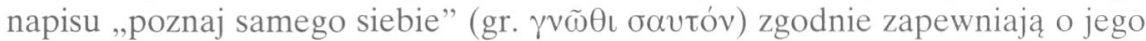
archaiczności, przypisując sformułowanie go w czasach mitycznych bogu Apollonowi, osobom związanym ze świątynią delficką (Pytia, dozorca świątynny Labys), poetce Femonoe albo w wiekach VII-VI przed Chr. - Siedmiu Mędr$\mathrm{com}^{1}$. Wobec tego pewne zdziwienie może budzić fakt, że najwcześniejszymi zachowanymi autorami, u których się pojawia, są dopiero pisarze IV wieku przed Chr., Platon i Ksenofont. Prawdopodobnie, wynika to ze słabego stanu zachowania pism filozofów jońskich, presokratyków i sokratyków. Jeśli rację

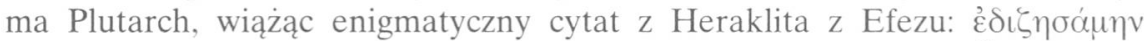

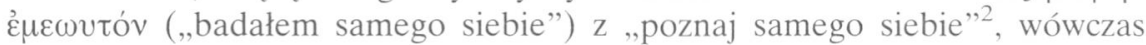
fragment 101B Heraklita byłby znacznie wcześniejszą niż pisma platońskie refleksją filozoficzną na temat delfickiego napisu.

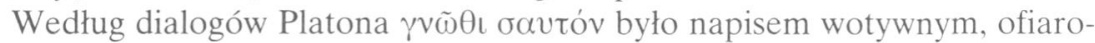
wanym Apollonowi jako „pierwociny mądrości” i umieszczonym na świątyni delfickiej przez Siedmiu Mędrców: Talesa z Miletu, Pittakosa z Mitylene, Biasa z Priene, Solona z Aten, Kleobulosa z Lindos, Myzona z Chen i Chilona ze

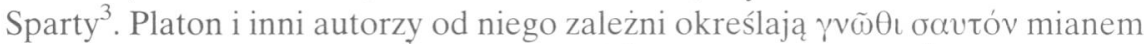
„napis delficki” ( także te niezależne od Platona, potwierdzają obecność tego i innych napisów

${ }^{1}$ Bardzo wiele źródeł wypowiada się na temat autorstwa $\gamma v \omega \bar{\omega} \theta \mathrm{t}$ oavtóv, por. m.in. Diogenes Laertios Vitae philosophorum 1, 40; Clemens Alexandrinus, Stromata I 14, 60, 3.

${ }^{2}$ Por. Plutarchus, Adversus Colotem 1118 C.

${ }^{3}$ Por. Plato, Protagoras 343a-b.

${ }^{4}$ Por. Plato, Phaedrus 229e5; Charmides 164d; Philebus 48c; Alcibiades I, 124a; Xenophon, Memorabilia Socratis 4, 2; Aristoteles, frg 1 (apud Plutarchum); Plutarchus, Consolatio ad Apollonium 116c; Philo Alexandrinus, Legatio ad Gaium 69, 1. 
w pronaosie (przedsionku) świątyni delfickiej. ${ }^{5}$ Już w czasach Platona napis ten był słynny, i jak pisze on sam, śpiewany przez wszystkich ${ }^{6}$. Możliwe, że Platon ma na myśli przekazany przez Scholia (i w podobnym brzmieniu przez Plutarcha) dwuwiersz poety Iona ${ }^{7}$, następującej treści: „Poznać siebie - w słowach nic wielkiego, ale w działaniu tylko bóg potrafi", do którego aluzję znajdujemy w Alkibiadesie $I^{8}$. Istnieje także tradycja, być może pośrednio zainspirowana przez samego Platona, którą przekazują Scholia do Fileba. Podobno - odnotowuje scholiasta - Chilon ze Sparty miał zapytać boga, co jest najlepszą rzeczą,

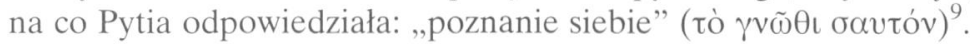

2. Rozumienie potoczne. Nasze źródła różnią się co tego, czym było $\gamma v \tilde{\omega} \theta$ เ

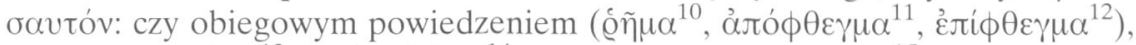

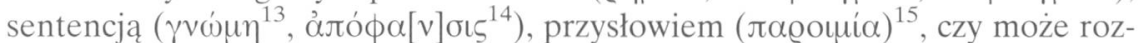

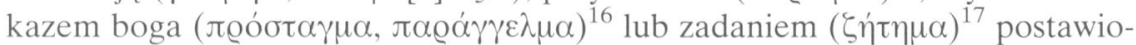
nym przed ludźmi. Scholiaści opowiadają się najwyraźniej za rozumieniem potocznym, zaliczając $\gamma v \tilde{\omega} \theta \iota$ oavtóv do kategorii przysłów mówiących, że żaden człowiek nie powinien pragnąć tego, co jest poza jego zasięgiem, takich jak: „nie skacz ponad rów” (tzn. „nie przebieraj miary”), „bij własną żonę” (tj. „zajmij się swoimi sprawami”) czy „nie bierz się do rzeczy niewykonalnych”18. Diodor Sycylijski wymienia $\gamma v \tilde{\omega} \theta \mathrm{c}$ oavtóv jednym tchem wraz z takimi maksymami starożytnych, jak: "nie zadzieraj nosa" i "los wszystkim rządzi"19. Komediopisarz Menander podaje szereg popularnych interpretacji $\gamma \nu \tilde{\omega} \theta \iota$

${ }^{5}$ Por. Xenophon, Memorabilia Socratis 4, 2; Plutarchus, De E apud Delphos, 385d-392a; Pausanias Periegeta, Graeciae descriptio 10, 24, 1.

${ }^{6}$ Plato, Protagoras 343 a-b.

7 Por. Plutarchus, Consolatio ad Apollonium 116d; Scholia in Platonem: Alcibiades 1, 129a = Fragmenta incertorum poetarum 389

${ }^{8}$ Por. Plato, Alcibiades I, 129a.

9 Por. Scholia in Platonem: Philebus 48c,5.

10 Por. Menander, Aspis 189.

11 Por. m.in. Scholia in Platonem: Philebus 48c, 5.

12 Por. Origenes, In Canticum Canticorum X 141.

13 Por. Aristoteles, Rhetorica 1395a.

14 Por. Diodorus Siculus, Bibliotheca historica XIII 24, 5.

15 Por. Scholia et glossae in Olympia et Pythia Pindari II 64, 1; Scholia in Platonem: Philebus $48 \mathrm{c}, 5$.

${ }_{16}$ Por. Pseudo-Plato, Alcibiades I, 130e; Plutarchus, Demosthenes 3, 3; De E apud Delphos 385d; Gregorius Thaumaturgus, In Origenem oratio panegyrica 11, 141; Epictetus, Dissertationes ab Arriano digestae I 13; Clemens Alexandrinus, Stromata V 8, 45 (cyt. Dionizjusza Traka).

17 Por. Sextus Empiricus, Adversus mathematicos VII 266.

18 Por. Scholia et glossae in Olympia et Pythia Pindari II 64, 1. Podobnie interpretują Scholia in Platonem: Philebus 48c, 5. (,,przysłowie dot. ludzi, którzy chełpią się rzeczami przekraczającymi ich możliwości”).

19 Por. Diodorus Siculus, Bibliotheca historica XIII 24, 5. 
бavтóv, takich jak: „znaj swoje miejsce”, „powinieneś wiedzieć, co masz robić”, „żyj dla innych, a nie tylko dla siebie"

Ślady potocznego rozumienia są zresztą widoczne także u filozofów. Arys-

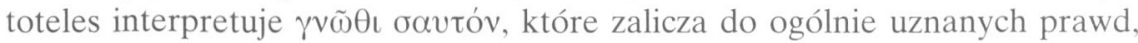
w następującym sensie: zrozum, że się nie nadajesz do pełnienia wysokich stanowisk $^{21}$. Ksenofont wkłada w usta Sokratesa opinię, że napis na świątyni w Delfach oznacza, iż należy poznać własne moźliwości, bo znajomość siebie, czyli własnych sił i zdolności, przynosi wielką korzyść w życiu, a nieznajomość ich - nieszczęśsie ${ }^{22}$. Tę opinię Ksenofonta powtarza w dużym skrócie Filon z Aleksandrii ${ }^{23}$. Nawet Plutarch, który wielokrotnie w bardzo subtelny, platonizujący sposób podchodzi do interpretacji napisu, w jednym miejscu zauważa, że poznanie siebie, nakazywane w zagadkowy sposób przez Apollona Pytyjskiego, to nic innego, jak poznanie swoich wad i zalet ${ }^{24}$. Charakterystyczną cechą niefilozoficznego rozumienia ,poznaj samego siebie” jest widoczna tendencja indywidualizująca, kładąca nacisk na poznanie swoich indywidualnych zdolności, cech charakteru, sytuacji życiowej, pozycji społecznej, itp., nieco zbliżona do naszego współczesnego podejścia do samopoznania.

3. Interpretacja filozoficzna. Plutarch z Cheronei trafnie zauważa, że rozkaz

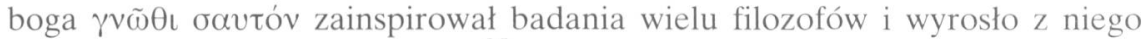
niczym z ziarna, mnóstwo słów ${ }^{25}$ - a trzeba zauważyć, że czasy Plutarcha poprzedzają ogrom literatury filozoficznej, jaki miał dopiero powstać na temat

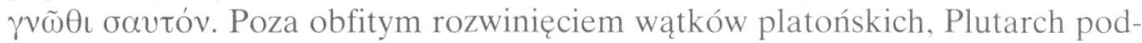
aje bardzo ciekawą informację, opartą tym razem nie na dialogach Platona, lecz na niezachowanych dialogach Arystotelesa, mianowicie, Arystoteles miał uznawać $\gamma \nu \tilde{o} \theta \iota$ oovtóv za punkt wyjścia dla filozoficznych badań Sokrate$\mathrm{sa}^{26}$. Przekaz jest ciekawy, ponieważ wydaje sie pochodzić z tradycji sokratycznej, nie będącej jednak tradycją platońską. Wiemy z bardzo ogólnikowej

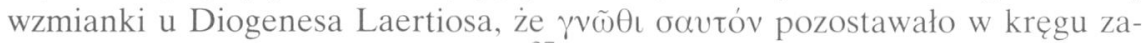
interesowań sokratyka Antystenesa ${ }^{27}$. Skąpość materiału nie pozwala jednak

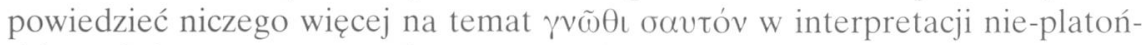
skiego Sokratesa; mamy obszerny przekaz Ksenofonta, o którym pisaliśmy wyżej, ale nie sposób go uznać za interpretację filozoficzną.

${ }^{20}$ Por. Menander, Aspis 189-193; Coneazomenae 1, 1-2; Pseudo-Menander, Sententiae I 584585.

${ }^{21}$ Por. Aristoteles, Rhetorica $1395 \mathrm{a}$.

22 Por. Xenophon, Memorabilia Socratis IV 2, 24-27.

23 Por. Philo Alexandrinus, Legatio ad Gaium 69, 1.

24 Por. Plutarchus, Quomodo adulator ab amico internoscatur 49b.

${ }^{25}$ Por. Plutarchus, De E apud Delphos 385d.

26 Por. Plutarchus, Adversus Colotem $118 \mathrm{c}=$ Aristoteles, frg. 1 .

27 Por. Diogenes Laertius, Vitae philosophorum I 40. 
Przejdźmy zatem do Platona, autora pierwszej zachowanej filozoficznej interpretacji napisu delfickiego. W dialogach Protagoras (343a-b) i Charmides (164d-165a) relacjonuje on genezę powstania delfickiego napisu; w pierwszym z nich przypisuje jego autorstwo Siedmiu Mędrcom, kultywującym według niego ,filozofię lakońską", a w drugim traktuje go jako słowa powitania

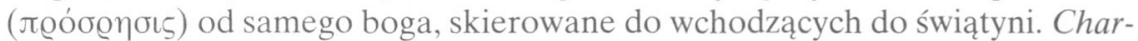
mides zawiera ponadto wyjaśnienie wyrażenia „poznaj samego siebie” po-

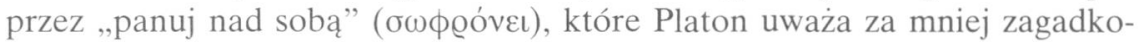

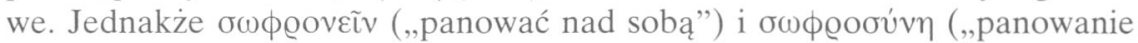
nad sobą", „umiarkowanie”), należące do tradycyjnych helleńskich pojęć, u Platona stały się terminami filozoficznymi, trudnymi do interpretacji i niemożliwymi do satysfakcjonującego przekładu na języki nowożytne. W Charmidesie $167 \mathrm{a}$,panowanie nad sobą" ( zostało zdefiniowane jako ,,poznanie siebie samego i wiedza o tym, co się

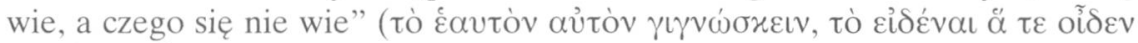

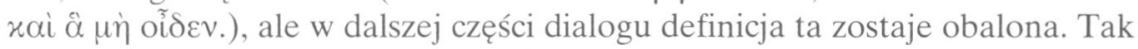

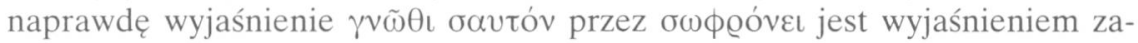
gadki przez inną zagadkę. W Timajosie 72a Platon nawiązując do tego wczesnego dialogu napisze: "robić swoje i poznać siebie samego potrafi tylko człowiek opanowany”, przy czym niezbyt dostojnie brzmiące „robić swoje” jest platońską definicją sprawiedliwości, a zatem należałoby to zdanie rozumieć następująco: postępować sprawiedliwie i poznać siebie potrafi tylko człowiek opanowany.

„Wiedza o wiedzy i wiedza o niewiedzy” z Charmidesa, jak zauważyli komentatorzy dialogu, pojawia się w bardzo podobnym sformułowaniu w platońskiej Apologii 21d, gdzie Sokrates przedstawia się jako ten, który nie sądzi, że coś wie, jeśli czegoś nie wie, a zatem jako człowiek „umiarkowany" ( $\sigma \omega ́ \phi \varrho \omega v)$ w rozumieniu platońskim ${ }^{28}$. W Apologii 20e-23b znajduje się dłuższe opowiadanie o początkach misji Sokratesa i o tym, co stało się impulsem dla jego filozoficznych dociekań. Spodziewalibyśmy się, że tym

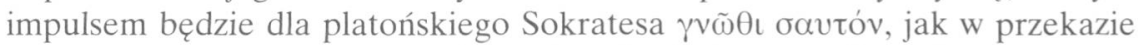
Plutarcha cytującego Arystotelesa, ale tak nie jest. Według Platona w stan „aporii” wprawiła Sokratesa wyrocznia boga w Delfach, który na pytanie Chajrefonta odpowiedział, że nie ma nikogo mądrzejszego od Sokratesa. Sokrates potraktował tę wyrocznię boga jako zagadkę do rozwiązania i doszedł do wniosku, że mądry jest jedynie bóg, a ludzka mądrość nie ma żadnej wartości, w związku z czym najmądrzejszym z ludzi jest ten, który zdaje sobie sprawę z własnej niewiedzy, przy czym niewiedza nie jest tym samym, co głupota (Apologia, 23a-b). Mimo tego, iż Platon nie chce otwarcie przyznać,

28 Por. H.H. Benson, A Note on Socratic Self-Knowledge in the Charmides, „Ancient Philosophy" 23 (2003) 31-47. 


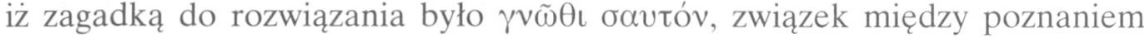
siebie a świadomością, że mądrość nie może być osiągnięta przez człowieka, wydaje się oczywisty ${ }^{29}$.

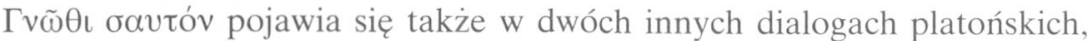
w Filebie 48c-49a i Fajdrosie 229e-230a, ale w negatywnym sformułowaniu jako „nieznajomość samego siebie” ( Sokrates wypowiada się bardzo krytycznie o ludziach, którzy nie znają samych siebie, to znaczy, żywią błędne przekonanie co do swego statusu majątkowego, urody i zalet charakteru, z tej racji, że błędne mniemanie o samym sobie staje się przyczyną zła moralnego. W Fajdrosie Sokrates mówi o sobie

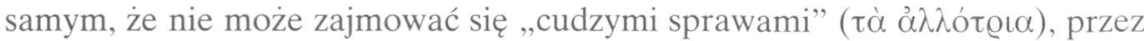
które rozumie alegorezę mitów, ponieważ nie zdołał jeszcze poznać siebie, jak głosi napis delficki. Poniechawszy zatem kwestii mitologicznych zgłębia sa-

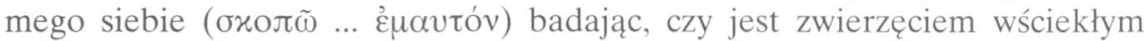
i powikłanym jak Tyfon, czy łagodniejszym i mającym z natury jakiś udział w boskości. Dalszy ciąg dialogu, jak zauważa Ch. Griswold, pokazuje, że platońskie samopoznanie nie ma nic wspólnego z wiedzą o sobie jako indywiduum, lecz chodzi w nim o poznanie duszy jako takiej, jej natury i funkcji ${ }^{30}$. Gdybyśmy chcieli w sposób bardzo ogólny podsumować platońskie wypowie-

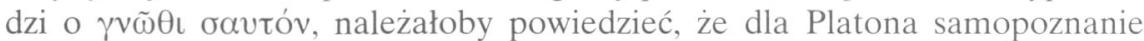
oznacza samowychowanie.

Pewnego rodzaju wątek mistyczny wprowadza do omawianego zagadnienia dialog Alkibiades I, co do autentyczności którego trwają od dawna zażarte spory, przy czym najnowsze opracowania uznają jednak jego autentycznośćc ${ }^{31}$. W dialogu tym delficki slogan staje się zagadnieniem centralnym, a jego omówieniu autor poświęca bardzo dużo miejsca (124a-133c). Po krótkiej wzmiance o „napisie w Delfach” (124a) następuje stwierdzenie, że poznanie siebie jest niezmiernie trudne (129a), co jest prawdopodobnie aluzją do zachowanego dwuwiersza Iona, a dalej pojawia się po raz pierwszy w literaturze greckiej kluczowe dla całego zagadnienia wyjaśnienie, że „poznanie samego

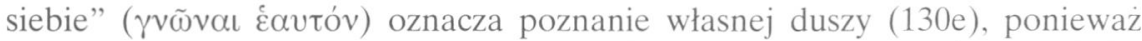
człowiek nie jest niczym więcej niż duszą (130b). Ważne jest także rozróżnienie między tym, co naprawdę „twoje”, czyli duszy, od „twoich rzeczy”, czyli

${ }^{29}$ Podkreślają to autorzy komentarzy: C.H. Kahn, Plato and the Socratic Dialogue. The Philosophical Use of a Literary Form, Cambridge 1996, 188-203; E.de Strycker - S.R.Slings, Plato's Apology of Socrates. A Literary and Philosophical Study with a Running Commentary, Leiden 1994, 62-68.

${ }^{30}$ Por. Ch. Griswold, Self-knowlegde and the 'idea' of the soul in Plato's Phaedrus, , Revue de Metaphysique et de Morale" 86 (1981) 477-494.

31 Autorzy najnowszych wydań i komentarzy do Alkibiadesa I opowiadają się za jego autentycznością, por. m.in. M.L. Desclos, Platon: Alcibiade, Paris 1996; C. Marboeuf - J.F. Pradeau, Platon: Alcibiade, Paris 1999; N. Denyer, Plato: Alcibiades, Cambidge 2001. 
ciała (131e). Sokrates zapowiada następnie (132d), że wyjaśni w sposób obrazowy znaczenie napisu delfickiego, i każe Alkibiadesowi wyobrazić sobie oko, któremu napis delficki kazałby oglądać samo siebie, a następnie zastanowić się, w jaki sposób oko może samo siebie oglądać. Odpowiedź jest dość prosta: oko musi patrzeć w lustro, odbicie w wodzie lub w inne oko, czyli we wszelkie rzeczy, które są do niego podobne ze względu na swą przejrzystość (133a-b). Analogicznie do oka, dusza, która chce poznać samą siebie, powinna wpatrywać się w duszę, a szczególnie w jej najbardziej boskie i podobne do boga miejsce, związane z poznaniem i myśleniem. W to miejsce się wpatrując jak w zwierciadło dusza pozna zarówno samą siebie, jak i boga. To najbardziej boskie miejsce duszy okazuje się być identyczne z bogiem, wobec czego wywód kończy się stwierdzeniem, że możemy poznać samych siebie wpatrując się w boga i posługując się nim jak najpiękniejszym zwierciadłem (133c). Autor pisma dochodzi więc do wniosku, że najwyższa część duszy człowieka jest identyczna z bogiem, ale waha się stwierdzić wprost: pamiętaj, że jesteś bogiem. Dialog ten nie stosuje platońskiego wyrażenia „oko duszy” ( $\psi v \chi \tilde{\eta}_{5}$ ő $\mu \alpha)^{32}$, choć jest ono zasugerowane przez porównanie myślącej części duszy do źrenicy, która odpowiada za widzenie.

Jeśli chodzi o pisarzy po Platonie, można ich podzielić na autorów, którzy tylko wyjaśniali czy rozwijali koncepcje Platona związane z $\gamma v \tilde{\omega} \theta \mathrm{\iota} \sigma \alpha v \tau o ́ v$, i na filozofów, którzy nadawali napisowi delfickiemu znaczenie odpowiadające ich własnemu systemowi filozoficznemu, nie troszcząc się o zgodność czy niezgodność z platonizmem. Plutarch z Cheronei, który będąc zagorzałym platonikiem i kapłanem w Delfach poświęcił napisowi delfickiemu sporo uwagi, wyciąga wnioski z wyżej omawianych fragmentów dialogów Platona, ale nie dokonuje oryginalnych innowacji. Uważa on, że dwa wspomniane przez Platona napisy delfickie ,poznaj samego siebie" i ,nic ponad miarę" znaczą jedno i to samo ${ }^{33}$. Plutarchowi pozwala tak sądzić fakt, że „nic ponad miarę" ma znaczenie zbliżone do „panuj nad sobą”, a między ,poznaj siebie” a „panuj nad sobą” został postawiony znak równości przez samego Platona w Charmidesie. Podobnie, rozwinięciem Charmidesa jest pismo O inskrypcji E w Delfach. Plutarch przypomina w nim czytelnikom pomysł Platona, że „poznaj siebie” jest powitaniem boga skierowanym do wchodzących i znaczącym mniej więcej tyle, co zwykłe greckie $\chi \alpha \tilde{\iota} \varrho \varepsilon$ (,witaj”). Pielgrzym odpowiada na to powitanie boga słowem $\varepsilon \tilde{\imath}$, które znaczy , ,istniejesz" ${ }^{34}$.

Innym autorem, który powołuje się na autorytet Platona i jednocześnie wysuwa wnioski z jego pism, jest Diodor Sycylijski. Diodor pisze, zapewne pod wpływem filozofii medioplatońskiej, że poznać siebie znaczy „stać się

\footnotetext{
32 Por. Plato, Respublica 533d; Sophista 254a.

33 Por. Plutarchus, Consolatio ad Apollonium 116c-d.

34 Por. Plutarchus, De E apud Delphos 392a.
} 


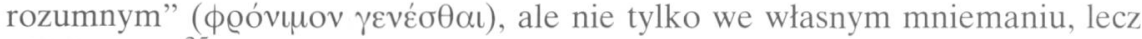
obiektywnie $^{35}$. Autor ten bardzo umiejętnie powiązał wątki z różnych dialogów

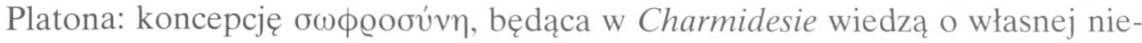

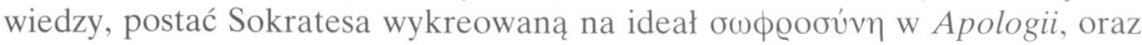
pojawiającą się w Teajtecie 176b definicję „upodobnienia się do boga”, w której pojawia się sformułowanie „stać się sprawiedliwym i świętym wraz ze zrozu-

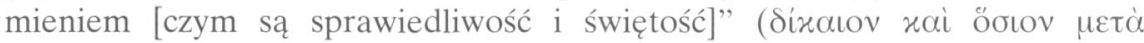

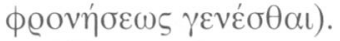

W czasach cesarstwa rzymskiego bardzo popularnym rozumieniem $\gamma v \tilde{\omega} \theta$ เ бavtóv było memento mori, („pamiętaj o śmierci”). W Dialogach zmarłych

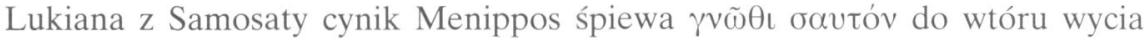
zmarłych bogaczy: Krezusa, Sardanapala i Midasa, co ewidentnie ma znaczenie: „pamiętaj o śmierci” ${ }^{36}$. Częste są również przedstawienia w sztuce okresu cesarstwa łączące wyobrażenie rozpadającego się trupa z napisem $\Gamma \mathrm{N} \Omega \Theta \mathrm{I}$ $\Sigma$ AYTON $^{37}$. Nadawanie delfickiemu napisowi tego rodzaju znaczenia wydaje się należeć do tzw. ludowego platonizmu, ale po dogłębnej analizie, jaką przeprowadził E. Jungel, okazuje się, że interpretacja taka wynika logicznie z dialogów Platona (Fedon, Gorgiasz), i można powiedzieć, jest syntezą platoniz$\mathrm{mu}^{38}$. Według Fedona (66e; 80a-81b) czyste poznanie, tj. poznanie Idei, zostanie zrealizowane tylko przez duszę wyzwoloną z cielesnych okowów, czyli po śmierci człowieka, przez co śmierć staje się dla duszy sposobem oczyszczenia, dzięki któremu dusza - będąc z natury boska - odzyskuje utracone poprzez wcielenie naturalne podobieństwo do boga i zdolność poznawania „sama przez się", tj. bez pomocy zmysłów. Dzięki temu, co zostało zasugerowane w dialogach Platona, że ,poznaj siebie” znaczy „poznaj swą boską naturę”, i że według niego pełna realizacja poznania siebie, to jest, boskości swej duszy, nie jest możliwa za życia człowieka, ,poznaj siebie” mogło zostać zinterpretowane jako „pamiętaj, że umrzesz”.

Powiedzieć wreszcie wypada o wielkich interpretacjach filozoficznych delfickiego napisu, których zależność od Platona można określić jako luźną. Jedna z nich pochodzi od stoików, a druga od Plotyna. Niezwykle istotne dla interpretacji patrystycznej źródła staro- i medio-stoickie są nam dostępne jedynie w wyrywkowych relacjach stoików rzymskich (głównie Epikteta) czy dzięki przypadkowym wzmiankom. Epiktet, z pewnością postępując za wcześniejszą stoicką tradycją, łączy napis na świątyni delfickiej z Sokratesowym wezwaniem

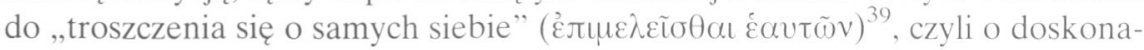

35 Por. Diodorus Siculus, Bibliotheca historica IX 10, 2-3.

36 Por. Lucianus Samosatensis, Dialogi mortuorum 2, 3.

37 Por. E. Jungel, Śmierć Sokratesa jako oddzielenie ciała i duszy, tłum. W. Torzewski. „Analiza i egzystencja” 3 (2006) 32-37.

38 Por. Jungel, Śmierć Sokratesa, s. 27-39.

39 Por. Epictetus, Dissertationes ab Arriano digestae III 1, 18-19. 
łość (đ̊@etí) własnej duszy, dobrze znanym także z dialogów Platona ${ }^{40}$. Dosko-

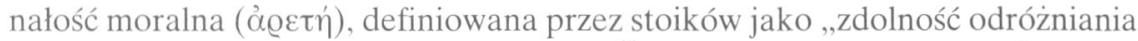

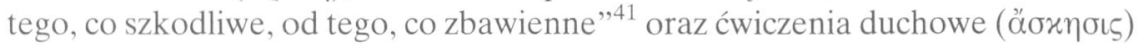
prowadzące do jej osiągnięcia, łączone były przez nich $\mathrm{z}$ tematem poznania siebie, o czym wiemy ze źródeł bardzo już późnych (Orygenes, Lukian z Samosaty $)^{42}$, ale poprzedzających jeszcze Bazylego, u którego wątek ten także występuje. Także od Epikteta wiemy, że rozkaz wyryty na świątyni w Delfach miał dla stoików nowy, nieplatoński sens, integralnie związany ze stoickim panteizmem i nauką o roli człowieka w świecie. „Poznaj siebie” oznacza zrozumienie faktu, że człowiek został stworzony przez naturę nie dla samego siebie, lecz po to, by postępował w sposób nie naruszający harmonii wszechświata, jak tancerz, który zna swoje miejsce w układzie choreograficznym i dokładnie wie, jakie ruchy powinien wykonywac ${ }^{43}$. Natomiast występująca u Epikteta interpretacja „poznaj samego siebie” jako odwrócenie się od „rzeczy zewnętrznych” ( $\varepsilon \xi \omega)$

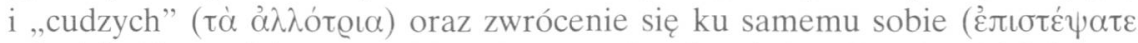

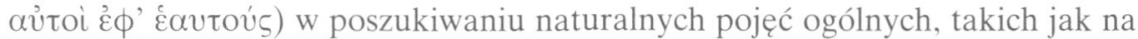
przykład dobro ${ }^{44}$, wydaje się być ewolucją poglądów wyrażonych w Alkibiadesie I. Zgodnie z Alkibiadesem I Epiktet przedstawia poznanie siebie jako konsulta-

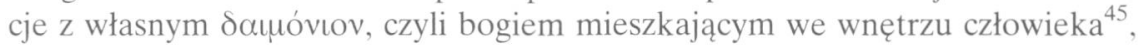
przy czym faktyczna tożsamość człowieka z bogiem w przypadku tak nieortodoksyjnego stoika pozostaje dyskusyjna.

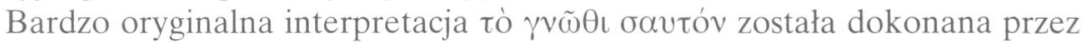
Plotyna, który przypisał temu powiedzeniu treść zgodną z własnym systemem filozoficznym. W swoich Enneadach ${ }^{46}$ Plotyn pisze, że powiedzenie „poznaj samego siebie" dotyczy bytów ludzkich, o wiele mniej doskonałych od Abso-

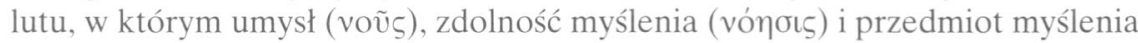
(voๆtóv) są tym samym, a także mniej doskonałych od bogów, którzy z kolei są mniej doskonali od Absolutu, i jako tacy mają zdolność myślenia oddzieloną od reszty (czyli umysłu i przedmiotu myślenia) jak gdyby coś w rodzaju oka. Ludzie zatem z powodu swej niedoskonałości i ,wielości samych siebie” ( $\pi \lambda \tilde{\eta} \theta 0 \varsigma$ $\varepsilon \alpha v \tau \tilde{\omega} v)$ nie mogą się doliczyć, ilu ich naprawdę jest wewnątrz, ani jakie są te części ich samych, ani która którą rządzi. To bardzo skomplikowane zagadnienie zostaje przez Plotyna szerzej rozwinięte w traktacie 49 o samo-

40 Por. Plato, Apologia 29e; Alkibiades I 127d. Szerzej na temat powiązania „poznaj siebie” i „troszcz się o siebie” u stoików i epikurejczyków, zob. Technologies of the Self. A Seminar with Michael Foucault, ed. L.H. Martin, London 1988, 16-49.

${ }^{41}$ Por. Diogenes Laertius, Vitae philosophorum VII 92.

42 Por. Origenes, In Canticum canticorum II 5; Lucianus Samosatensis, De saltatione 81.

43 Por. Epictetus, Dissertationes ab Arriano digestae I 13-24.

${ }^{44}$ Por. tamze III 22, 38-39.

45 Por. tamze III 22, 53; II 8, 11-14; I 14, 12-15.

${ }^{46}$ Por. Plotinus, Enneades VI 7, 41. 
poznaniu $^{47}$. W traktacie tym nie ma jednak bezpośredniego odniesienia do

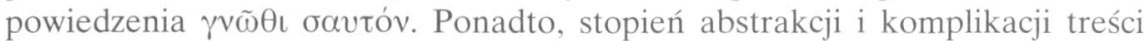
tego pisma był tak wysoki, iż nie mógł wywrzeć większego wpływu na Ojców

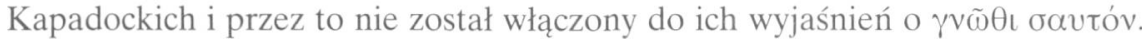
Uczeń Plotyna, Porfiriusz, który bardzo silnie oddziaływał m.in. na Bazylego, miał napisać według Sudy, aż cztery księgi na temat „Poznaj samego siebie”

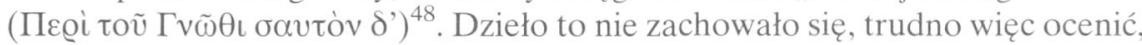
czy miało bardziej przystępny charakter niż Enneady (V 3 [49]).

4. Tradycja aleksandryjska. Odrębną kwestią jest interpretacja $\gamma v \tilde{\omega} \theta \iota$ бavtóv przez Szkołę Aleksandryjską. Charakterystyczne dla interpretacji aleksandryjskiej jest pełne wykorzystanie tradycji platońskiej oraz dopełnienie jej wątkami biblijnymi lub chrześcijańskimi. Filon Aleksandryjski odnosi się do „poznaj siebie” w kilku miejscach, ale najbardziej oryginalna jest jego idea niemożliwości poznania samego siebie przez umysł (voũ $)$, która jest wątkiem nieplatońskim (w Alkibiadesie I samopoznanie jest uznawane za bardzo trudne, ale nie za niemożliwe). Przyczyną niepoznawalności własnego umysłu jest według Filona fakt stworzenia umysłu na obraz obrazu Boga, czyli Logosu

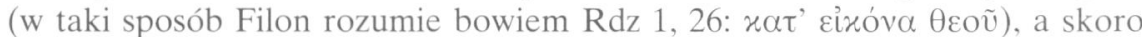
Bóg jest niepoznawalny ( $\alpha$ x $\alpha \tau \dot{\alpha} \lambda \eta \pi \tau o \varsigma)$, umysł ludzki, który jest odblaskiem jego obrazu, musi być także niepoznawalny (ă $\gamma v \omega \sigma \tau o \varsigma)^{49}$. Pomimo doskonałej znajomości Alkibiadesa I i nawiązania do niego (porównanie umysłu do oka), Filon odrzuca zaproponowane tam rozwiązania:

„To, że umysł w każdym z nas może wszystko inne zrozumieć, ale nie może poznać samego siebie. Jak bowiem oko widzi wszystko inne, ale nie widzi siebie, tak samo i umysł, może wszystko inne pojmować, ale nie może pojąć sam siebie" ${ }^{\text {"50 }}$.

Bardzo istotne jest powiązanie przez Filona samopoznania z samowychowaniem, co jest uogólnionym wnioskiem z myśli platońskiej, natomiast niezmiernie ważne i wręcz kluczowe dla literatury chrześcijańskiej, stanie się

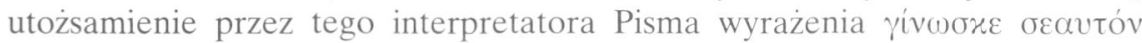

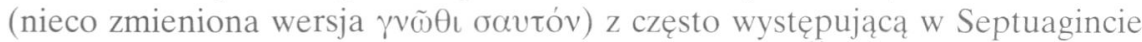

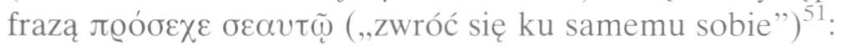

${ }^{47}$ Por. tamże V 3; M.F. Hazebroucq, La connaissance de soi-même et ses difficultés dans l'Ennéade V, 3 et le Charmide de Platon, w: La connaissance de soi: études sur le Traité 49 de Plotin, ed. M. Dixsaut, Paris 2002, 107-131.

${ }^{48}$ Por. Suidas, Lexicon pi. 2098, 8.

49 Por. Philo Iudaeus, De mutatione nominum 10; Legum allegoriae I 91; De somniis I 56-58; zob. też M. Osmański, Filona z Aleksandrii etyka upodobniania się do Boga, Lublin 2007, 73

${ }^{50}$ Philo Iudaeus, Legum allegoriae I 91, tłum. L. Joachimowicz: Filon Aleksandryjski, Pisma, t. 1, Warszawa $1986,107$.

51 W Septuagincie $\pi \varrho o ́ \sigma \varepsilon \chi \varepsilon ~ \sigma \varepsilon \alpha u \tau \tilde{~}$ występuje 16 razy: Rdz 24, 6; Wj 10, 20; 23, 21; 43, 12; Pwt 4, 9; 6, 12; 8, 11; 11, 16; 12, 13. 19. 30; 15, 9; 24, 8; Tb 4, 12 i 14; Syr 29, 20. 
„Ponieważ jesteś królem, wychowaj siebie tak, aby rządzić, a nie być rządzonym, i poznawaj siebie przez całe życie, tak jak także Mojżesz często poucza, mówiąc: "Zwróć się ku samemu sobie»" "52.

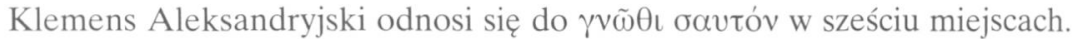

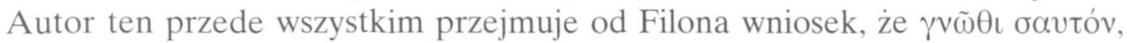
choć ani razu nie występuje w Septuagincie, tak naprawdę jest tam obecne, ponieważ Mojżesz wielokrotnie używa zwrotu $\pi \varrho o ́ \sigma \varepsilon \chi \varepsilon ~ \sigma \varepsilon \alpha v \tau \tilde{\omega}$ (,zwróć się ku

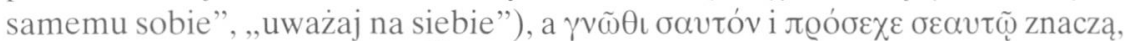
zdaniem Klemensa, to $\mathrm{samo}^{53}$. Poprzez to stwierdzenie Klemens wprowadza

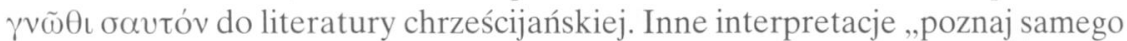
siebie” to: „pamiętaj o śmierci” i „pamiętaj, że jesteś człowiekiem”, ${ }^{\text {, }}$ które należy uznać za wyjaśnienia będące konsekwencją platonizmu, oraz rozumienie napisu delfickiego jako poznanie celu, dla którego zostaliśmy stworzeni przez Boga, jako konieczność zachowywania przykazań i uzyskania zbawienia $^{55}$. To ostatnie, choć wydaje się interpretacją na wskroś nowatorską (tj. chrześcijańską), faktycznie jednak może być reminiscencją interpretacji stoickiej (poznanie siebie to zrozumienie celu, dla jakiego stworzyła nas natura, czyli Bóg) oraz pogłębionej lektury Filona.

Św. Grzegorz Taumaturg pokazuje, jak ważne miejsce zajmowała

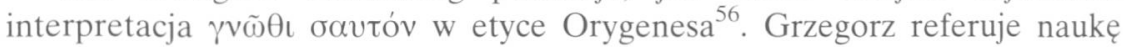
Orygenesa o mądrej wskazówce, złożonej jako napis wotywny najbardziej wieszczemu spośród demonów. Poza znanymi wątkami platońskimi z Charmidesa (poznanie siebie to panowanie nad sobą) i Alkibiadesa I (motyw doskonałości duszy, @’@etí, jako zwierciadła, w którym dusza ogląda samą siebie), relacja owa przekazuje pogląd Orygenesa o tym, że zwrócenie się do wnętrza jest równoznaczne ze sprawiedliwym postępowaniem i moralnym życiem,

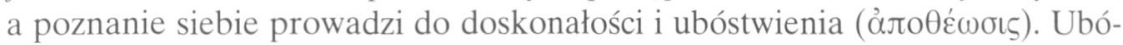
stwienie jest moźliwe dzięki temu, że człowiekowi przysługuje zdolność pojmo-

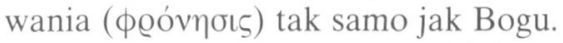

U samego Orygenesa znajdujemy wypowiedź na temat ,poznaj samego siebie” w Komentarzu do Pieśni nad Pieśniami ${ }^{57}$. Orygenes zajmuje się tym tematem, ponieważ zauważa oczywistą zbieżność między cytatem z Pnp 1, 8

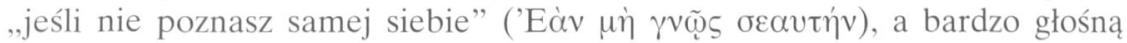

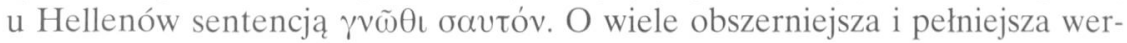

${ }^{52}$ Philo Iudaeus, De migratione Abrahami 8. To ważne miejsce wskazuje u Filona Kittel: Maıdía and vónos in Philo, TWNT V 613..

53 Por. Clemens Alexandrinus, Stromata II 15, 71, 3.

54 Por. tamże V 4, 23, 1.

55 Por, tamże VII 3, 20, 7-8.

56 Por. Gregorius Thaumaturgus, In Origenem oratio panegyrica 11, 138-144.

57 Por. Origenes, In Canticum Canticorum X 141-142 (wersja grecka), II 5 (wersja łacińska). 
sja łacińska Komentarza ujmuje samopoznanie w dwóch aspektach: (1) refleksji nad swymi uczynkami dobrymi i złymi (rachunek sumienia), analizy emocji i indywidualnych skłonności, i (2) poznania przez duszę jej własnej natury, co stanowi według Orygenesa część poznania stworzenia bożego. Ten drugi rodzaj samopoznania, który można nazwać ogólnym albo teoretycznym, jest uznawany przez Orygenesa za znacznie trudniejszy od pierwszego, wobec czego autor uważa, że polecenie „poznaj samego siebie” w tym drugim sensie jest skierowane nie do wszystkich, ale tylko do wybranej duszy, którą PnP 6, 9 nazywa ,jedyną i doskonałą”. Ten bardzo ważny w patrystycznej interpretacji „poznaj samego siebie” tekst Orygenesa, który będzie jeszcze analizowany niżej, wiąże problematykę samopoznania z ćwiczeniami duchowymi, takimi jak rachunek sumienia, z pewnością czyniąc to pod wpływem tekstów stoickich, a także epikurejskich i neopitagorejskich, dla nas straconych $^{58}$.

\section{II. „SKIERUJ UWAGE NA SIEBIE SAMEGO” ZNACZY „POZNAJ SAMEGO SIEBIE” U BAZYLEGO}

W pismach Bazylego Wielkiego fraza $\gamma v \tilde{u} \theta \mathrm{t}$ oavtóv nie pojawia się ani razu. Mamy natomiast sformułowania: „poznać samego siebie” (غ̇avtòv

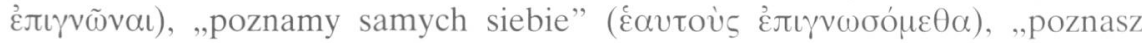

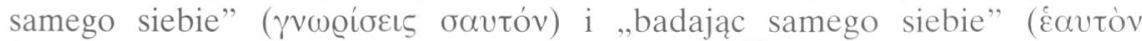

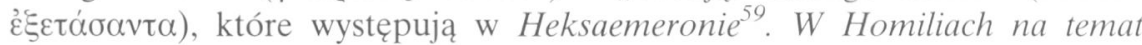

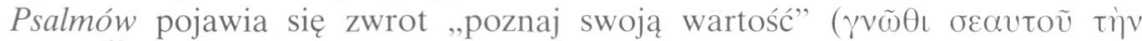
$\left.\alpha^{\prime} \xi \dot{\xi} \alpha v\right)^{60} \mathrm{w}$ kontekście omawianej problematyki. Ale najpełniejszy zestaw te-

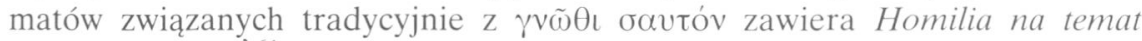

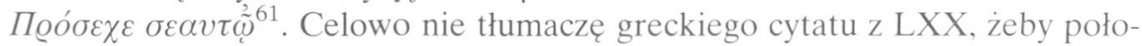
żyć nacisk na niemożliwość satysfakcjonującego przekładu na język polski i na

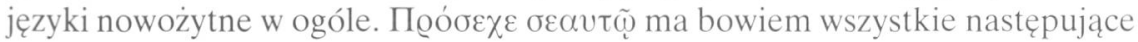
znaczenia: „uważaj na siebie”, „skieruj uwagę na siebie samego”, ,skup się na sobie samym", „skoncentruj się na sobie samym" 62 . Fraza ta traktowana jest

${ }^{58}$ Por. P. Hadot, Filozofia jak ćwiczenie duchowe, tłum. P. Domański, Warszawa 2003, 69-93; Technologies of the Self, s. 16-49.

${ }^{59}$ Por. Basilius Caesariensis, Homiliae in Hexaemeron IX 6, PG 29, 204, lub SCh 26bis, 512. lub GCS NF 2, 158; VI 1, PG 29, 117, lub SCh 26 bis, 328, lub GCS NF 2, 88.

${ }^{60}$ Por. Basilius Caesariensis, Homiliae super Psalmos 48, 8. PG 29, 452.

${ }^{61}$ Por. Basilius Caesariensis, Homilia in illud: „Attende tibi ipsi”, PG 31, 197-217; wydanie krytyczne, na którym opiera się tekst niniejszego artykułu: L'homélie de Basile de Césarée sur le mot 'Observe-toi toi-même'. Édition critique du texte grec et étude sur la tradition manuscrite par S.Y. Rudberg, Stockholm 1962.

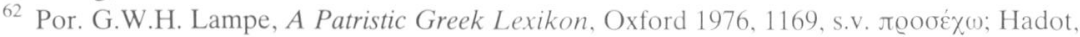
Filozofia jako ćwiczenie duchowe, s. 69-93. 


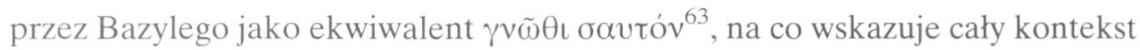
jej użycia, między innymi, przypisanie $\pi \varrho o ́ \sigma \varepsilon \chi \varepsilon ~ \sigma \varepsilon \alpha v \tau \tilde{\omega}$ takiego oto znaczenia: „Badaj samego siebie, kim jesteś, poznaj swoją własną naturę” ('E $\xi \dot{\varepsilon} \tau \alpha \sigma o v$

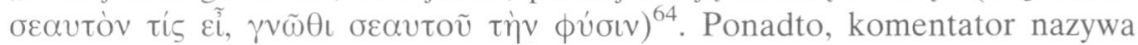

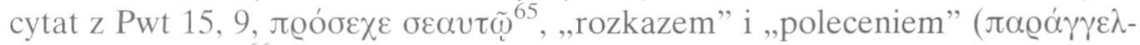
$\mu \alpha, \pi \varrho o ́ \sigma \tau \alpha \gamma \mu \alpha)^{66}$ - a są to przecież określenia tradycyjnie nadawane właśnie napisowi delfickiemu. Tym, co pozwoliło Bazylemu na tego rodzaju nadinterpretację ${ }^{67}$, było miejsce z Kobierców Klemensa Aleksandryjskiego, które brzmi następująco: „Jeszcze wyraźniej wskazuje Mojżesz na zasadę «Poznaj samego siebie» mówiąc często «Uważaj na siebie»"68. Sam zaś Klemens, jak zaznaczono wyżej, oparł się z kolei na wcześniejszej interpretacji Filona z Aleksandrii.

\section{CO ZNACZY SFORMUŁOWANIE „SAMEGO SIEBIE” U BAZYLEGO?}

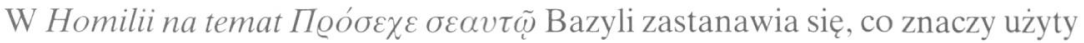

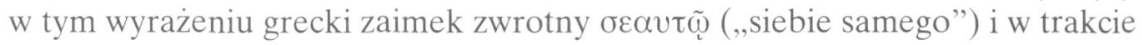
deliberacji dochodzi do wniosku, że „skieruj uwagę na siebie samego” znaczy: „skieruj uwagę na własną duszę"69. Wniosek ten nie ma raczej związku z komentowanym wersetem biblijnym, lecz jest transpozycją ważnego tekstu na temat poznania siebie, a mianowicie Alkibiadesa I $130 \mathrm{a}-\mathrm{e}^{70}$, gdzie Sokrates

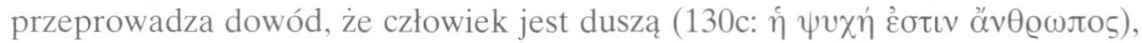
a zatem rozkaz boga każący poznać samego siebie oznacza, że mamy poznać

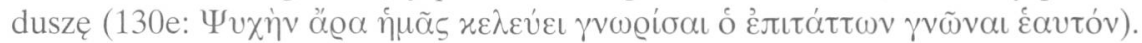

Bazyli wyróżnia w człowieku jak gdyby trzy warstwy: najbardziej wewnętrz-

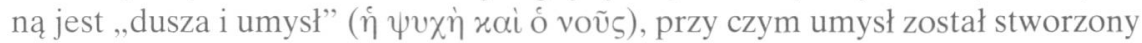

63 Jest to pogląd powszechnie przyjmowany, por. np. C. Moreschini, Storia della filosofia patristica, II Brescia 2005, 527-528.

${ }^{64}$ Basilius Caesariensis, Homilia in illud: „Attende tibi ipsi” 3, s. 27, 11 (dalej cytuję i podaję lokalizację wg wydania krytycznego).

${ }^{65}$ Fraza $\pi \varrho o ́ \sigma \varepsilon \chi \varepsilon ~ \sigma \varepsilon \alpha v \tau \tilde{\omega}$ występuje w LXX wielokrotnie (zob. wyżej). Bazyli zaznacza na wstępie, w rozdz. 1, że będzie komentować właśnie to miejsce - Pwt 15, 9 („Uważaj na siebie samego, aby słowo ukryte w twoim sercu nie stało się przekroczeniem prawa"), por. Basilius Caesarienis, Homilia in illud: „Attende tibi ipsi” 1, s. 24.

66 Por. Basilius Caesariensis, Homilia in illud: „Attende tibi ipsi” 2, s. 25, 13 i 24.

${ }^{67}$ Bez wątpienia, należy przyznać rację P. Hadot, który odnosząc się do tego właśnie kazania Bazylego, napisał (Czym jest filozofia starożytna?, tłum. P. Domański, Warszawa 2000, 311): „Aluzja do tekstów biblijnych opiera się często wyłącznie na interpretacji alegorycznej, która sprowadza się do nadania tekstom sensu, jaki się im nadać pragnie, zgoła nie uwzględniającego intencji ich autora".

68 Clemens Alexandrinus, Stromata II 15, 71, 3, tłum. J. Niemirska-Pliszczyńska, I, Warszawa $1994,177$.

${ }^{69}$ Por. Basilius Caesariensis, Homilia in illud: „Attende tibi ipsi” 3, s. 27, 7.

70 Por. Th. Špidlík, La sophiologie de S. Basile, Roma 1961, 101-102. 
na obraz Boga, następnym kręgiem jest ciało i spostrzeżenia zmysłowe, i jako ostatni, najbardziej odległy od wnętrza, zostaje wymieniony stan posiadania ${ }^{71}$. To miejsce Bazylego przypomina znaną stoicką koncepcję człowieka jako koncentrycznych, coraz bardziej rozszerzających się kręgów, zwaną oixzíwoıs ${ }^{72}$, którą opisuje współczesny Epiktetowi stoik Hierokles we fragmencie zachowanym w antologii Stobajosa pod tytułem, Jak należy żyć z krewnymi ${ }^{73}$. Do tego właśnie, jak gdyby centrum człowieka, „duszy i umysłu”, odnosi się zaimek zwrotny „siebie samego”, argumentuje w tym samym miejscu Bazyli, odróżniając „siebie samego” od „twoich rzeczy” ( $\tau \dot{\alpha} \sigma \alpha \dot{)})$, za które uważa ciało i doznania zmysłowe, oraz od rzeczy „wokół ciebie” ( $\tau \dot{\alpha} \pi \varepsilon \varrho i ~ \sigma \varepsilon ́)$, czyli rzeczy należących do człowieka, takich jak np. majątek. Rozróżnienie między „sobą samym”, „twoim” i „wokół ciebie” jest niemal identyczne jak to przeprowadzone przez Sokratesa w Alkibiadesie I 131e.

Charakterystyczny sposób wypowiadania się zawiera fragment, gdzie „siebie samego”, „twoje” i „rzeczy wokół ciebie” zostało zastąpione przez „my

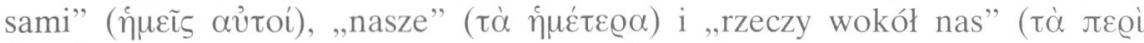
$\dot{\eta} \mu \tilde{\alpha} \varsigma)$. Autor osiąga w ten sposób następujący efekt:

„My jesteśmy duszą i umysłem [...], nasze jest ciało i wrażenia zmysłowe, wokół nas znajdują się pieniądze, itd." ${ }^{74}$.

Wyrażenie „my”, jako odnoszące się do istoty człowieka, własnego „,ja”, zostało zapożyczone od Plotyna, który lubił stosować zwrot np. „my jesteśmy duszą"75. Z pewnością zwrot ten został przejęty przez Plotyna z wcześniejszej literatury filozoficznej (np. podobnie Alkibiades I, 128e) czy nawet z języka mówionego. Występujące u Bazylego i w innych tekstach wyrażenie „my jes-

71 Por. Basilius Caesariensis, Homilia in illud: „Attende tibi ipsi” 3, s. 26.

72 Więcej na temat oikeiosis por. R. Sorabji, Animal Minds and Human Morals, The Origins of the Western Debate, London 1993, 122-133 i 177. Koncepcja ta występowała już we wczesnej Stoi, u Zenona z Kition, por. Porphirius, De abstinentia 3, 19 - 3, 20.

${ }^{73}$ Por. Hierocles, Fragmenta ethica 61= Stobaeus, Florilegia 84, 23 (vol. III, p. 134, 1 Mein.): „Każdy z nas jest opisany jak gdyby wieloma kręgami, mniejszymi i większymi, zarówno otaczającymi, jak i otaczanymi [przez inne kręgi]. Pierwszy i najbliższy jest ten krąg, który - jak gdyby

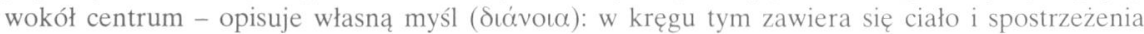
zmysłowe. Jest to krąg najmniejszy i najbliższy środka. Drugi po nim i bardziej oddalony od środka, otaczający krąg pierwszy, jest krąg, w którym znajdują się rodzice, bracia, żona i dzieci. A po nich następuje krąg trzeci, w którym są stryjowie, ciotki, dziadkowie i babki, i dzieci braci, a nadto kuzynki. Po tym kręgu następuje krąg, który obejmuje pozostałych krewnych. A po nim kolejny obejmujący członków tego samego demu, następny członków tej samej fyli, jeszcze dalsze współobywateli, sąsiadów, rodaków. Najodleglejszy i największy, obejmujący wszystkie kręgi, to krąg całego rodzaju ludzkiego". Wszystkie przekłady z języka greckiego, o ile nie zaznaczono inaczej, pochodzą od autorki artykułu.

${ }^{74}$ Por. Basilius Caesariensis, Homilia in illud: , Attende tibi ipsi” 3, s. 26, 17

75 Por. Plotinus, Enneades I 1, 7, 6; I 1, 10, 1; III 4, 3; V 3, 3; VI 4, 14. Czasem thumacze, jak czyni to np. A. Krokiewicz, thumaczą plotyńskie „my” przez „jaźń”. 
teśmy duszą" można byłoby przełożyć ,ja jestem duszą", co jest przyjęte i stosowane przez tłumaczy z zastrzeżeniem, że nie należy wiązać z tym nowożytnej problematyki ,ja”. Pojawiająca się w omawianym tekście definicja ,ja” (w tekście oryginalnym: „siebie samego” i „my sami”) jest określana przez badaczy jako platońska czy też stoicko-platońska ${ }^{76}$.

\section{PIECĆ DRÓG INTERPRETACJI „POZNAJ SIEBIE SAMEGO” U BAZYLEGO}

1. Zwróć się ku samemu sobie. Jedna z dróg interpretacji, przedstawionych

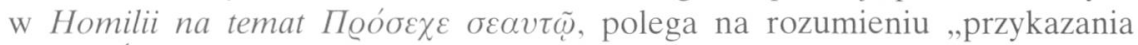
Ducha Świętego" w sensie poniechania myśli o cudzych grzechach (dosł. „nie

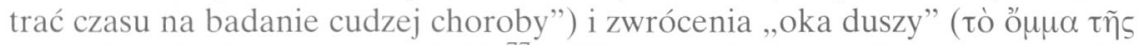
$\psi v \chi \tilde{\eta} \varsigma)$ ku badaniu samego siebie ${ }^{77}$. „Oko duszy”, znane sformułowanie platońskie $^{78}$, zostaje dla jeszcze większej jasności wyjaśnione przez autora jako

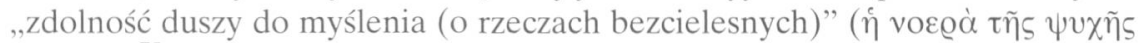

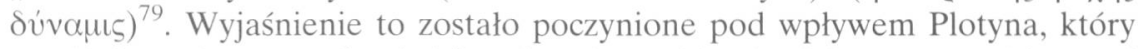
wyróżnia w duszy, czyli całościowej osobowości człowieka, trzy części: umysł

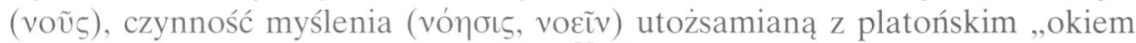
duszy", oraz przedmiot myśli (voךtóv) ${ }^{80}$. Zwrócenie się duszy od rzeczy zewnętrznych ku samej sobie było z kolei toposem, zwłaszcza w stoicyzmie i neoplatonizmie $^{81}$. A zatem użyta przez Bazylego fraza „zwróć oko duszy ku ba-

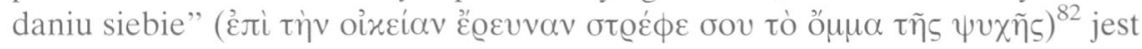
całkowicie zgodna z tradycją platońską i neoplatońską.

Jednakże zgodność z platonizmem nie sięga zbyt głęboko, co się okazuje, gdy czytamy przeprowadzone przez Bazylego porównanie czynności umysłu do widzenia oczu, które nawiązuje do Alkibiadesa I. Bazyli interpretuje w tym miejscu „zwróć uwagę na samego siebie” jako „oglądaj się ze wszystkich stron" ( $\pi \alpha v \tau \alpha \chi o ́ \theta \varepsilon v ~ \sigma \varepsilon \alpha v \tau o ̀ v ~ \pi \varepsilon \varrho เ \sigma \chi o ́ \pi \varepsilon l)$. Uważa on taką czynność, jak oglądanie samego siebie, za całkowicie niemożliwą do wykonania przez oczy cielesne, wobec czego wyprowadza wniosek, że polecenie to - ponieważ jest niewykonalne fizycznie - musi odnosić się do oka duszy, czyli czynności umysłu ${ }^{83}$. Jest

${ }^{76}$ Por. Špidlík, La sophiologie de S. Basile, s. 133-134; Hadot, Filozofia jak ćwiczenie duchowe, s. 77, przypis 33 .

77 Por. Basilius Caesariensis, Homilia in illud: „Attende tibi ipsi” 5, s. 31, 19.

78 Por. Plato, Sophista 245a; Respublica 533d.

79 Por. Basilius Caesariensis, Homilia in illud: „Attende tibi ipsi” 2, s. 25, 22.

${ }^{80}$ Por. Plotinus, Enneades VI 7, 41.

81 Por. np. Epictetus, Dissertationes ab Arriano digestae III 22, 39; Plotinus, Enneades V 3, 3.

${ }^{82}$ Basilius Caesariensis, Homilia in illud: „Attende tibi ipsi” 5, s. 31, 18-19.

83 Por. tamże 2, s. 26, 5. 
to bardzo interesujące miejsce. Przypomnijmy, że w Alkibiadesie I znajduje się analogiczne porównanie widzenia oczu do czynności wykonywanej przez umysł, ale w tym dialogu samo-oglądanie się oka nie jest bynajmniej uważane za niemożliwe, wręcz przeciwnie: oko może bez większych problemów oglądać samo siebie, jeśli spojrzy np. w lustro lub w oczy innego człowieka. W dalszej części tegoż dialogu za zwierciadło, dzięki któremu dusza może sama siebie oglądać, został uznany bóg, tożsamy z najwyższą i najdoskonalszą częścią duszy, odpowiedzialną za myślenie (lokalizacja miejsc, por. wyżej). Zatem, Bazyli postępuje tu za treścią Alkibiadesa I do pewnego tylko miejsca, wyznaczonego wcześniej przez Filona z Aleksandrii ${ }^{84}$, ale dalej już nie, bo kontynuacja toku myślenia z Alkibiadesa I doprowadziłaby do przyjęcia tezy, że człowiek jest z natury bogiem. Zaznaczmy na marginesie, że Mowa pochwalna na cześć Orygenesa Grzegorza Taumaturga stosuje metodę zwierciadła w samopoznaniu dokładnie za Alkibiadesem I, co staje się równoznaczne $\mathrm{z}$ apoteozą człowieka ${ }^{85}$.

2. Poznaj Boga poprzez samego siebie. Zanim przedstawimy teksty z dwóch pism Bazylego, będące przykładami interpretacji, którą można umownie nazywać teleologiczną, powróćmy na chwilę do wspomnianej już wypowiedzi Orygenesa z Komentarza do Pieśni nad Pieśniami (II 5). Orygenes stara się połączyć tradycję stoicką z platońską poprzez odróżnienie samopoznania w aspekcie praktycznym (ćwiczenia ascetyczno-moralne, tj. rachunek sumienia) od samopoznania $\mathrm{w}$ aspekcie teoretycznym. Poznanie samego siebie w aspekcie teoretycznym należy uznać za pewien wyższy poziom samopoznania, ponieważ Orygenes zaznacza, że jest ono przeznaczone dla wybranych, podczas gdy praktyczne jest dla wszystkich. „Wyższe” samopoznanie duszy jest częścią wiedzy, wiedza bowiem dzieli się na poznanie Trójcy Świętej i poznanie stworzenia Bożego, którego część stanowi właśnie samopoznanie duszy. Samopoznanie teoretyczne, będące rodzajem wiedzy czy nauki, polega na znalezieniu odpowiedzi na pytania od dawna stawiane przez filozofów, takie jak: czy dusza jest materialna czy niematerialna, z ilu części jest złożona, czy została stworzona czy jest niestworzona, czy podlega reinkarnacji, czy istnieją inne byty rozumne analogiczne do niej, czy jest boska z natury. Z łatwością dają się rozpoznać wśród tych pytań zagadnienia, które Platon porusza w Fajdrosie w kontekście samopoznania odnośnie do wyglądu, natury i funkcji duszy.

U Bazylego znajdujemy syntezę platońsko-orygenesowego samopoznania duszy jako części stworzenia ze znaną stoicką nauką o poznaniu Boga poprzez

${ }^{84}$ Por. Philo Alexandrinus, Legum allegoriae I 91, jego omówienie wyzej.

85 Por. Gregorius Thaumaturgus, In Origenem oratio panegyrica 11, 142, tłum. S. Kalinkowski, ŹMT 11, 69: ,,słusznie mówili starożytni [...], że sama dusza ogląda samą siebie i boski umysł jak w zwierciadle, jeśli jest godna zjednoczenia z bogiem, i przeglądając się w sobie samej podąża niewypowiedzianą jakąś drogą ku apoteozie". 
obserwację świata $^{86}$, przejętą przez Szkołę Aleksandryjską. Poznanie Boga, opisywane w terminach stoickich, takich jak ,naturalne pojęcie Boga” $(\dot{\eta}$

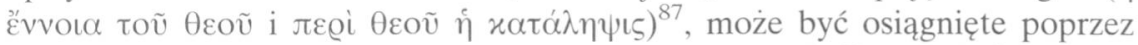

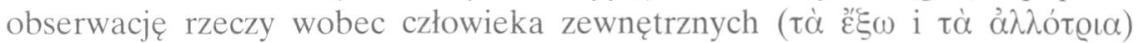

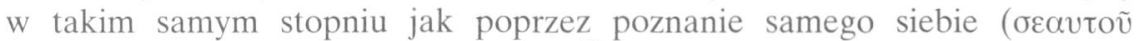

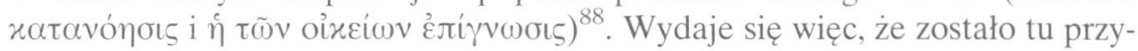
jęte stoickie założenie, że człowiek ma się do świata tak, jak część do całości, stąd poznanie świata i poznanie samego siebie są w swej istocie tym samym, i jeśli można uzyskać jakieś wyobrażenie o Bogu na podstawie obserwacji świata, to na podstawie obserwacji samego siebie również.

Jeśli natomiast zadamy pytanie, czy Bazyli konsekwentnie stosuje założenie, że człowiek jest integralną częścią świata (to znaczy: zarówno jego ciało, jak i umysł należą do świata i partycypują w jego strukturze), to będziemy musieli na to pytanie odpowiedzieć: nie. Według wyrażenia użytego przez

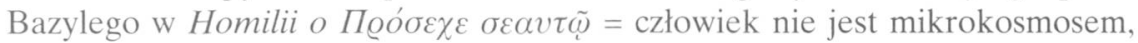
ale jest ,,jak gdyby mikrokosmosem":

„W sobie samym, jak gdyby w jakimś mikrokosmosie, zobaczysz wielką mądrość

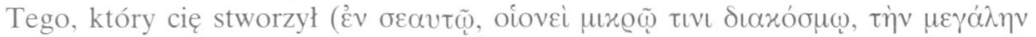

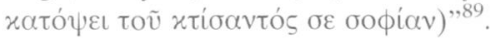

Zagadnienie, dlaczego Bazyli nie mógł nazwać człowieka mikrokosmosem, dlaczego idea mikrokosmosu jest dla niego możliwa do przyjęcia jedynie w sensie metaforycznym, może być wyjaśnione na podstawie całościowego opracowania zagadnienia mikrokosmizmów w filozofii starożytnej i późniejszej, jakie przedstawił R. Allers ${ }^{90}$. Żeby idea mikrokosmosu mogła zostać przyjęta $\mathrm{w}$ jakimkolwiek $\mathrm{z}$ czterech podawanych przez autora opracowania znaczeń (mikrokosmizm elementarystyczny, strukturalny, holistyczny i symboliczny), należy zaakceptować istnienie Duszy Świata, oraz wierzyć, że wszechświat jest przez takową siłę ożywiany. Bazyli natomiast odrzuca koncepcję duszy świata, wobec czego idea mikrokosmosu w żadnym z czterech wymienionych sensów jest niemożliwa do przyjęcia ${ }^{91}$. Bazyli odwołuje się w tym miejscu do tzw. mikrokosmizmu psychologicznego lub metaforycznego (który de facto mikrokosmizmem już nie jest), pochodzącego od Arystotelesa, w którego sys-

${ }^{86}$ Por. Stoicorum Veterum Fragmenta (= SVF), coll. Joannes ab Arnim, II, nr 1009-1010,

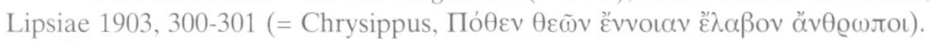

${ }^{87}$ Na temat terminów ennoia i katalepsis, ich genezy i użycia przez Bazylego, por. Moreschini, Storia della filosofia patristica, s. 522-523.

88 Por. Basilius Caesariensis, Homilia in illud: „Attende tibi ipsi” 7, s. 35, 12 i 22; Hexaemeron IX 6, PG 29, 204, lub SCh 26bis, 512, lub GCS NF 2, 158.

${ }^{89}$ Basilius Caesariensis, Homilia in illud: „Attende tibi ipsi” 7, s. 35, 14-15.

90 Por. R. Allers, Microcosmus from Anaximandros to Paracelsus, ,Traditio” 2 (1944) 319-407.

91 Por, tamże, s. 356, przypis 93; por. Basilius Caesariensis, Hexaemeron III 9, PG 29, 76AB. 
temie kosmologicznym nie było miejsca dla Duszy Świata. Według Arystotelesa bowiem dusza ludzka przez myślenie czy poznawanie wszechświata staje

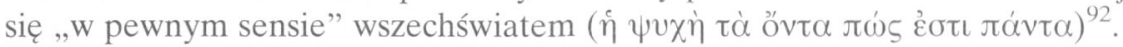

Wypada wreszcie przyjrzeć się, w jaki sposób wygląda poznanie Boga za pośrednictwem ,samego siebie”, czyli ,jak gdyby mikrokosmosu”. Na podstawie obserwacji samego siebie można stwierdzić przez analogię do duszy mieszkającej w człowieku, że Bóg jest niematerialny, niewidzialny i daje się poznać jedynie na podstawie swego działania. Bazyli w sposób bardzo szczegółowy omawia najpierw związki duszy z ciałem, posługując się terminami stoickimi

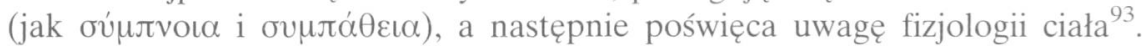
Obserwacja zatem samego siebie jest tu traktowana tak samo jak badanie przyrody, które - przez analogię - może dostarczyć pewnych, aczkolwiek bardzo ogólnikowych informacji na temat Stwórcy.

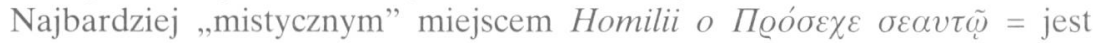
efektowny cytat:

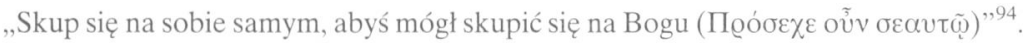

Zdanie to zestawione zostało ze sławnym wersetem z Księgi Psalmów (Ps 138, 6), często cytowanym przez Bazylego: „Cudowne poznanie Ciebie uzyskałem

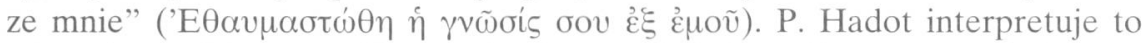
tajemnicze miejsce w takim sensie, że samoświadomość oznacza świadomość Boga $^{95}$, a N. Russell w takim, że samopoznanie jest warunkiem upodobnienia się do Boga ${ }^{96}$. Ten sam cytat $\mathrm{z}$ Księgi Psalmów pojawia się też w zakończeniu Heksaemeronu, również w kontekście samopoznania, gdzie Bazyli tłumaczy go w ten sposób: „przez poznanie siebie zostałem pouczony o nadzwyczajnej mądrości w Tobie". Bazyli pisze tam, nawiązując do Alkibiadesa I, że:

„poznanie samego siebie wydaje się być naprawdę najtrudniejszą ze wszystkich

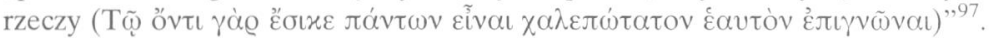

Można się zastanawiać, dlaczego to poznanie siebie jest takie trudne, skoro -

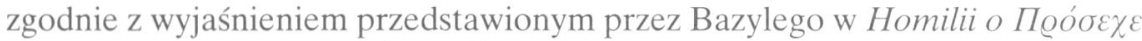

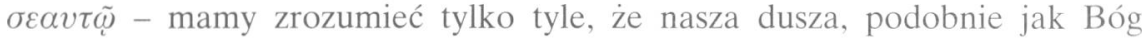
w świecie, jest niematerialna, niewidzialna i porusza ciałem. Wydaje się, że to miejsce Heksaemeronu jest odniesieniem do jakiegoś wątku mistycznego, którego Bazyli nie zamierza jednak rozwijać. Zakończenie Heksaemeronu

\footnotetext{
92 Por. Aristoteles, De anima 431b, 21-23; por. Allers, Microcosmus, s. 330 i 383-385.

93 Por. Basilius Caesariensis, Homilia in illud: „Attende tibi ipsi” 7, s. 35

94 Tamże 8, s. 37, 14-15.

95 Por. Hadot, Filozofia jak ćwiczenie duchowe, s. 80.

96 Por. Russell, The Doctrine of Deification in the Greek Patristic Tradition, Oxford 2005.
} 211-212.

97 Basilius Caesariensis, Hexaemeron IX 6, PG 29, 204, lub SCh 26bis, 512, lub GCS NF 2, 158. 
zapowiada, ale też zupełnie pomija wyjaśnienie, co znaczy stworzenie człowieka „na obraz i podobieństwo”, odsyłając do następnych homilii, które nie zostały nigdy napisane ${ }^{98}$. Jeśli mogę pozwolić sobie na pewną supozycję, to nadzwyczajna trudność poznania siebie, o której mówi autor w tekście, wskazuje, że ma on na myśli poznanie ,istoty” (oủoía) duszy, czyli, że nie chodzi tu o wyliczanie jej cech, takich jak np. niewidzialność, ale o pełne poznanie jej istoty. W taki sam sposób, w jaki Bazyli zaprzecza możliwości poznania ,istoty” Boga, tak samo uważa za niepoznawalną , istotę" wszystkich rzeczy stworzo-

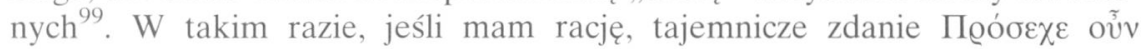

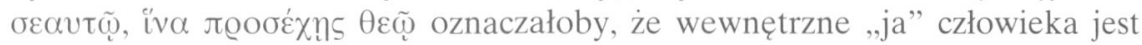
tak samo niepoznawalne jak , istota” Boga, co byłoby nawiązaniem do Filona, który uważał poznanie Boga i poznanie siebie za równie niemożliwe. Św. Grzegorz z Nyssy wyraża wprost konkluzję myśli, która pozostała niedokończona u Bazylego, pisząc, że jeśli ktoś chce poznać Boga, niech pozna samego siebie. Jedno i drugie jest niewykonalne, ponieważ stworzona na obraz Boga myśląca i nieśmiertelna „istota duszy” (

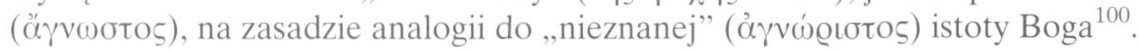

3. Troszcz się o duszę. Przenosimy się teraz ze sfery intelektualnej w moralną. Skupienie się na samym sobie, czyli swojej duszy, ma bowiem

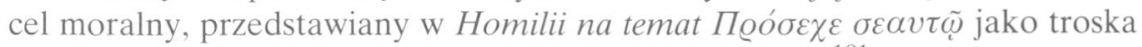
o duszę (,troszcz się o duszę, element nieśmiertelny”) ${ }^{101}$. Dbałość o duszę w kontekście samopoznania jest dobrze znana z Epikteta, który przypisuje tego rodzaju interpretację Sokratesowi ${ }^{102}$, ale u Bazylego ma ona więcej wspólnego z Platonem, niz z Epiktetem, albowiem Bazyli na sposób typowo platoński przedstawia ciało jako czynnik antagonistyczny wobec duszy. Troska o duszę oznacza dla niego zaniedbywanie ciała: im skrajniejsze będzie to zaniedbanie, w tym lepszej kondycji znajdzie się dusza. „Troszcz się o swoją duszę" jest równoznaczne z brakiem dbałości o zdrowie, wygląd, a nawet pokarm (,nie tucz ciała i nie dbaj o tę kupę mięsa”). Człowiek jako złożony z dwóch walczących ze sobą elementów różnej natury, tj. ciała i duszy, musi starać się przywrócić kontrolę elementu lepszego i nieśmiertelnego nad słabszym i śmiertelnym ${ }^{103}$.

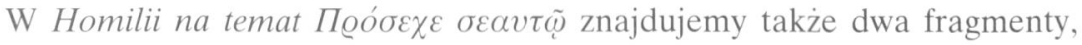
które opisują badanie siebie w terminach praktyk ascetyczno-moralnych, ta-

98 Por. D.T. Runia, Philo and the Church Fathers, Leiden 1995, 126-143.

99 Jeśli chodzi o stopień poznawalności Boga odsyłam do opracowania: Špidlík, La sophiologie de S. Basile, s. 130-137 i 188-193.

100 Por. Gregorius Nyssenus, Ad imaginem Dei et ad similitudinem, PG 44, 1332.

101 Por. Basilius Caesariensis, Homilia in illud: „Attende tibi ipsi” 3, s. 27, 16.

102 Por. Epictetus, Dissertationes ab Arriano digestae III 1, 18-19.

103 Por. Basilius Caesariensis, Homilia in illud: „Attende tibi ipsi” 3, s. 27. 
kich jak nieustanna analiza swoich myśli i czynów (rachunek sumienia), wyznanie grzechów, żal za grzechy, skrucha, czuwanie i post ${ }^{104}$. Miejsce to z pewnością zostało zainspirowane Orygenesowym Komentarzem do Pieśni nad Pieśniami. Orygenes ujmuje tam samopoznanie w system, którego niższym szczeblem praktycznym, jest właśnie rachunek sumienia, przeznaczony dla wszystkich chrześcijan, podczas gdy wyższy szczebel, teoretyczny, zastrzeżony został tylko dla wybranych. Wersja łacińska Komentarza do Pieśni nad Pieśniami (II 5) omawia rachunek sumienia w sposób bardzo szczegółowy. Tekst ten w oryginalnej redakcji greckiej musiał być dobrze znany Bazylemu, a jednak nie idzie on za Orygenesem w rozróżnieniu samopoznania dla tłumu i dla wybranych. Reliktem tego Orygenesowego rozróżnienia jest u Bazylego jedynie uwaga, że wszyscy powinni czynić rachunek sumienia, bo popełnianie grzechów jest rzeczą ludzką.

Celem, do którego się dąży poprzez praktyki ascetyczno-moralne, będące przejawem troski o duszę, jest moralna doskonałość, identyczna z możliwością osiągnięcia wiecznego zbawienia, którą Bazyli obszernie przedstawia zgodnie ze stoicką nauką jako zdolność odróżniania tego, co szkodzi, od tego, co

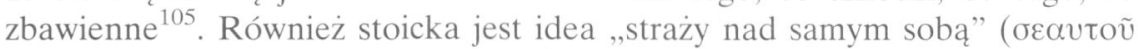

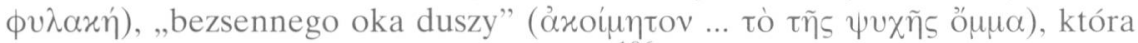
pojawia się w kontekście dbałości o duszę ${ }^{106}$.

4. Panuj nad sobą. Interpretacja poznania siebie, jako panowania nad silnymi emocjami takimi jak gniew czy żądze cielesne, jaką znajdujemy

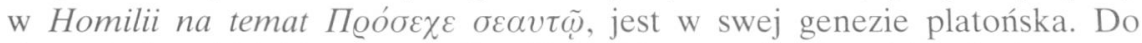
sławnej platońskiej interpretacji z Charmidesa nawiązuje także użycie w tym

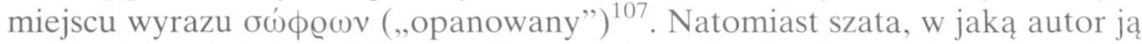
przybrał, jest już chrześcijańska. Panowanie nad wybuchami gniewu i poskramianie żądz ma się dokonywać według Bazylego poprzez przywoływanie w myśli obrazów wiecznej kary w piekle (jadowity robak, wieczny ogień), bo to pozwala przywrócić kontrolę rozumu nad zmysłami. Wtedy to przyjemności, przerażone perspektywą wiecznej i strasznej kary, uciekną w popłochu, a wewnątrz duszy zapanuje spokój (íovxía) ${ }^{108}$ i cisza taka, jak wtedy, gdy w komnacie pełnej rozwrzeszczanych służebnych zjawia się „opanowana”

104 Por. tamże 5, s. 31-32; 4, s. 28-29.

105 Por. tamże 2, s. 25; zob. też stoicką definicję cnoty w: Diogenes Laertius, Vitae philosophorum VII 92; Origenes, In Canticum canticorum II 5.

106 Por. Basilius Caesariensis, Homilia in illud: „Attende tibi ipsi” 2, s, 26, 5-6; zob. Epictetus, Dissertaiones ab Arriano digestae I 14, 12.

107 Por. Basilius Caesariensis, Homilia in illud: „Attende tibi ipsi” 7, s. 34-35.

108 'Houxía (spokój jako warunek pamięci i myśli o Bogu), to termin techniczny, związany z życiem duchowym, wspólny dla Bazylego i etyki pitagorejskiej, epikurejskiej, plotyńskiej i porfiriańskiej, por. A. Meredith, Asceticism - Christian and Greek, JTS 27 (1976) 313 -332. 
( $\sigma \dot{\phi} ф \varrho \omega v)$ pani. Możemy tu mówić o pewnym spłyceniu czy spopularyzowaniu interpretacji platońskiej, która - gdyby została przedstawiona zgodnie $\mathrm{z}$ intencjami jej autora - byłaby zapewne zbyt trudna do zrozumienia dla odbiorców homilii.

Motyw samokontroli został dodatkowo powiązany z trzeźwym osądem własnej sytuacji, pozycji, stanu majątkowego, itp. i z mocnym stąpaniem po ziemi: „bądź trzeźwy, zaradny, pilnuj tego, co masz [...] i nie obiecuj sobie używania tego, czego nie masz, a może i nie będziesz miał". Dalej następuje bardzo mocna i obszerna krytyka młodych ludzi, którzy bujają w obłokach, wyobrażając sobie bogactwa, których nie będą posiadać, i zaszczyty, których nigdy nie dostąpią ${ }^{109}$. Taka interpretacja samopoznania, jako rezygnacja z pragnienia rzeczy nieosiągalnych, jest zgodna z potocznym rozumieniem delfickiej maksymy, jaką znajdujemy m.in. u Menandra i u scholiastów, a poniekąd także z myślą wyrażoną w platońskim Filebie 48c-49a.

5. Pamiętaj, że jesteś człowiekiem. Jest to chrześcijańska modyfikacja tematu „pamiętaj o śmierci”, bo w taki sposób - jak pokazaliśmy wyżej - napis delficki był rozumiany przez ,ludowy” platonizm. Samo memento mori zajmuje niezbyt wiele miejsca u naszego autora, Bazyli wzmiankuje ten wątek, ale go nie rozwija (,,Skup się na sobie samym, wiedząc, że jesteś śmiertelny, że ziemią jesteś i do ziemi powrócisz"110). Badanie czy poznawanie własnej, ludzkiej natury ma dla Bazylego sens bardziej nakierowany na nieśmiertelność duszy (,troszcz się o duszę, która jest nieśmiertelna”) ${ }^{111}$ niż na śmiertelność ciała czy znikomość spraw doczesnych. Szeroko omawiana przez Bazylego koncepcja

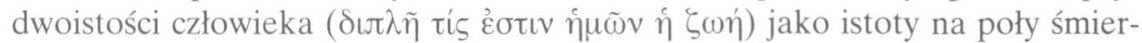
telnej, a na poły nieśmiertelnej, jest dobrze znanym toposem z filozofii helleńskiej $^{112}$. Pamięć o „naturze ludzkiej”, jako w połowie śmiertelnej i z tego powodu słabej, nakazuje być pokornym, a nie zarozumiałym (,Jeśli więc będziesz pamiętał o naturze ludzkiej, nigdy nie będziesz się wynosił" $)^{113}$, co przypomina

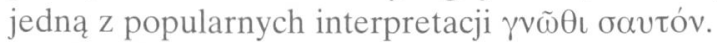

Dominująca u Bazylego jest natomiast tendencja w interpretacji $\gamma v \tilde{\omega} \theta \iota$ бavtóv, która podkreśla nie znikomość, lecz przeciwnie, godność człowieka i jego wyjątkowe miejsce we wszechświecie. Pojawia się ona w kilku jego pismach, między innymi w Heksaemeronie:

„Poznasz samego siebie, to znaczy: że jesteś ziemski z natury, że jesteś dziełem boskich rąk, pozostającym w tyle za nierozumnymi zwierzętami pod względem siły, a mimo to panującym nad nierozumnym i nieożywionym stworzeniem. [...]

109 Por. Basilius Caesariensis, Homilia in illud: „Attende tibi ipsi” 4-5, s. 30.

110 Tamze 5, s. 32, 11-12, por. Rdz 3, 19.

111 Tamże 3, s. 27, 16.

112 Por. tamże 3, s. 27, 12; na temat źródeł, por. Śpidlík, La sophiologie de S. Basile, s. 100-108.

113 Basilius Caesariensis, Homilia in illud: „Attende tibi ipsi” 5, s. 32, 20. 
Jeśli zrozumiemy to, poznamy samych siebie, poznamy Boga, oddamy pokłon Stwórcy" $" 114$.

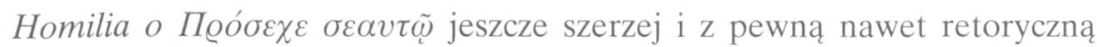
przesadą rozwija temat ludzkiej supremacji nad światem zwierzęcym (,są tobie poddane i podległe zwierzęta lądowe: domowe i dzikie, wszystkie zwierzęta wodne i wszystkie latające”) ${ }^{115}$ i przyrodą nieożywioną (,czyż nie otwarłeś sobie mórz za pomocą rozumu? Czyż ziemia i morze nie służą twojemu życiu?") ${ }^{116}$. Sposób ujęcia przez Bazylego toposu dominacji człowieka nad światem materialnym bardzo przypomina grecką wersję Księgi Syracha (7, 1-4), według której Bóg przyodziewa człowieka - ulepionego z ziemi i mającego do ziemi powrócić - w moc podobną do swojej, stwarzając go na swój obraz i powołując do panowania nad zwierzętami i ptactwem.

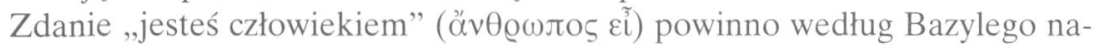
pawać dumą i sprawiać najwyższą radość, ponieważ człowiek jest jedyną we wszechświecie istotą, której ciało zostało uformowane rękoma samego Boga (por.Rdz 2, 7), stąd jego dostojny wygląd i nietypowa dla zwierząt wyprostowana postawa (dobrze rozpoznawalny motyw z Timajosa 90a-b), dusza zaś, także w drodze wyjątku, została stworzona na „obraz Boga” (por. Rdz 1, 27) ${ }^{117}$.

W Homiliach o Psalmach Bazyli pisze: ,poznaj swoją wartość” ( $\gamma v \tilde{\omega} \theta$.

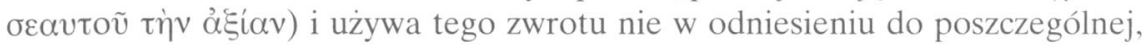
indywidualnej jednostki ludzkiej (tak jak używa się tego zwrotu dzisiaj), lecz odnośnie do człowieka w ogóle, stworzenia Bożego, które przez Stwórcę zostało otoczone niezwykłą czcią, a następnie odkupione za cenę krwi Chrystu$\mathrm{sa}^{118}$. Interpretacja poznania siebie w sensie uświadomienia sobie swej godności jako człowieka w ogóle, ma także cel moralny, bo poprzez świadomość swej ludzkiej godności i dumę z niej człowiek będzie (czy przynajmniej powinien) postępować w sposób godny i właściwy nawet w sytuacji niesprzyjającej, spowodowanej np. przez ubóstwo ${ }^{119}$.

\section{$* * *$}

Charakterystyczną cechą wszystkich przedstawionych wyżej interpretacji „poznaj samego siebie” jest całkowity brak motywu, jaki w czasach nowożytnych jest obowiązkowo łączony z samopoznaniem, a mianowicie, analizowania

114 Basilius Caesariensis, Homiliae in Hexaemeron VI 1, PG 29, 117, lub SCh 26bis, 328, lub GCS NF 2, 88 .

115 Basilius Caesariensis, Homilia in illud: „Attende tibi ipsi” 6, s. 33, 11-13

116 Tamże 6, s. 33, 15-16.

117 Por. tamze 6, s. 33, 5; 8, s. 36.

118 Por. Basilius Caesariensis, Homiliae super Psalmos 48, 8, PG 29, 452.

119 Por. Basilius Caesariensis, Homilia in illud: „Attende tibi ipsi” 6, s. 33-34 
własnego ,ja" w aspekcie indywidualistycznym. Pomijanie swoich własnych cech indywidualnych w badaniu „samego siebie" jest niewątpliwie dziedzictwem platońskim, przejętym przez późniejszą tradycję, w tym aleksandryjską. Sprawia to takie wrażenie, jak gdyby indywidualna osobowość dla takich autorów jak Orygenes, Bazyli czy Grzegorz z Nazjanazu (który także

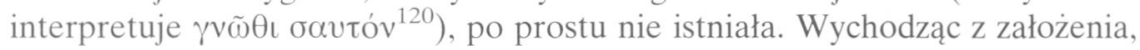
platońskiego w swej genezie, że to, co jednostkowe, musi być gorsze od tego, co uniwersalne, pisarze ci w interpretacji ,poznaj samego siebie” nie przywiązują wagi do badania cech indywidualnych, ale zastanawiają się nad człowiekiem w ogóle, jego miejscem i rolą w świecie, budową ciała, strukturą duszy, itp ${ }^{121}$. W klasycznych interpretacjach maksymy $\gamma \nu \tilde{\omega} \theta \iota$ oavtóv było marginalnie obecne coś, co nazwaliśmy tendencją indywidualistyczą, ale nie należało ono nigdy do głównego nurtu, zdominowanego przez platonizm, lecz do potocznego jej rozumienia.

Poza uogólniającym, anty-indywidualistycznym podejściem do poznania samego siebie, inną cechą, która odróżnia ujęcie patrystyczne od nowoczesnego, jest zapatrywanie na cel samopoznania. Dla nas celem, dla którego warto poznawać własną osobowość, jest własne szczęście, spełnienie, samorealizacja tu i teraz, na ziemi, w życiu doczesnym. Takie ujęcie występuje wprawdzie u Ksenofonta, ale jego interpretacja nie wpłynęła na Szkołę Aleksandryjską ani na Ojców Kapadockich. Ujęcie patrystyczne, idąc drogą wskazaną przez Platona, pomija szczęście doczesne jako obojętne czy mało istotne, a za cel, o który warto walczyć, uważa moralną doskonałość (Orygenes), równoznaczną z upodobnieniem się do Boga (Orygenes u Grzegorza Taumaturga). W interpretacjach Bazylego na temat „poznaj samego siebie” nie został zaakcentowany wątek upodobnienia do Boga, natomiast za cel, do którego dąży się poprzez poznanie siebie (czyli: troskę o duszę, panowanie nad sobą, praktyki ascetyczno-moralne, postępowanie zgodne z ludzką godnością, dążenie do poznania Boga), została uznana zdolność odróżniania tego, co szkodliwe, od tego, co zbawienne (stoicka definicja cnoty) z wyraźnym odniesieniem do zbawienia duszy.

120 Por. Gregorius Nazianzenus, Oratio 32: De moderatione in disputando 26, PG 36, 204-205, tłum. pol.: Św. Grzegorz z Nazjanzu, Mowy wybrane, Warszawa 1967, 378.

121 Por. G.C. Stead, Individual personality in Origen and the Cappadocian Fathers, w: Arche e telos. L'antropologia di Origene e di Gregorio di Nissa. Analisi storico-religiosa, ed. U. Bianchi-H. Crouzel, Milano 1981, 170-191. 


\section{'KNOW THYSELF' IN ST. BASIL'S INTERPRETATION}

\section{(Summary)}

There are some references to the famous Delphic inscription „Know thyself”

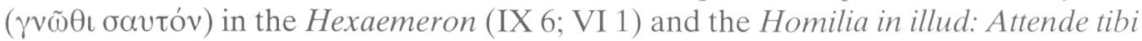
ipsi by St. Basil of Caesarea. In the Homilia in illud: Attende tibi ipsi St. Basil accepts

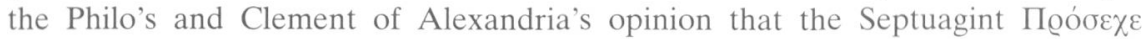

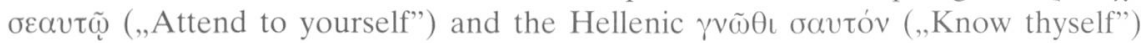
are the same. According to St. Basil, influenced by the Alcibiades I, „yourself" means ,a soul” as an opposite to a body and its environment. St. Basil interprets the Delphic maxim in the following meanings: (1) „Turn to yourself”, (2) „Know God from yourself”, (3) „Take care of your soul”, (4) „Control yourself”, and (5) "Remember you are a human". His interpretation is influenced by the many philosophical writings, especially the Platonic dialogues (the Charmides, the Alcibiades I), the Stromata of Clement of Alexandria, and the Origen's In Canticum canticorum. 